\title{
THE INFLUENCE OF THE CROWN IN THE EVOLUTION OF RESPONSIBLE GOVERNMENT
}

$\mathrm{T}^{\mathrm{H}}$

E Durham Report will always remain a turning point in British colonial policy. In its recommendations lay the genesis of responsible government. The ultimate wisdom of that policy is not now doubted, but at the time it met with considerable opposition and misunderstanding, even in comparatively Liberal quarters in England. In Canada its complete. realization was not secured until ten years after the publication of the Report.

The years between 1839-1849 are, therefore, of considerable importance in Canadian history. The evolution from representative to responsible government meant ten years of bitter contention and party controversy. The struggle was not so much whether or not Canada was to enjoy responsible government, but what interpretation of that theory was to hold the field. The four governors of that period, Sydenham, Bagot, Metcalfe, and Elgin, as well as the leaders of the Canadian Reform party, all agreed that they were following the principles enunciated in the Durham Report, but they all differed when they considered how those principles were to be put into practice. This fact is on the surface peculiar when it is remembered that the language of the Durham Report is remarkably clear and dogmatic in tone, quite unlike the usual blue book, and contains none of the reservations and ambiguities which are natural to the discreet politician. What is the explanation?

Professor Morison, in a recent book, ${ }^{1}$ traces the evolution of Canadian self-government during this period. Brilliant and suggestive as the book is, he nevertheless fails to reconcile the difference between the conception of responsible government as understood by Metcalfe and by Elgin. He is inclined to emphasize the limitations imposed by Durham. ${ }^{2} \mathrm{He}$ argues with effect that Metcalfe was quite right in claiming that he

${ }^{1}$ British Supremacy and Canadian Self-Government, $1839-1854$.

'Ibid., p. 243. 
was carrying out the principles of the Durham Report, ${ }^{1}$ and he suggests that the now abandoned theory that Durham did not write his own Report is true." "Even if Durham contributed more to his Report than seems probable," he writes, "the view there propounded of the scope of Responsible Government is not nearly so urgent as that of the latter pamphlet". ${ }^{3}$

These views are open to criticism. The subjects reserved for imperial control - the waste lands of Canada, trade relations, and foreign policy - had nothing to do with the struggle between 1839-49. The first was abandoned by the Mother Country, and the rest were admitted by the colonial reformers. There is no need to say anything on the subject of the authorship of the Durham Report. That topic has been discussed by Professor Egerton $^{4}$ and by Mr. F. Bradshaw in his book Self-Government in Canada. Whatever may have been the share of Durham, Buller, and Wakefield, there is little reason to suggest that the Report was not equally the expression of the views of all three. If Durham was strongly influenced by anyone-and his political career in England does not lend support to such a view-he was more likely to be influenced by Wakefield, well known for his arts of persuasion, than by Buller, who was fourteen years his junior. There is no evidence to suggest that the three men were ever in disagreement on the theory of colonial government. Durham died less than eighteen months after the publication of the Report; Buller remained closely connected with Wakefield's schemes of colonization till his death in 1848, and was referred to by Wakefield as his "alter ego". Finally Buller's pamphlet, Responsible Government in the Colonies, was published during the lifetime of Durham. It was meant as a fuller explanation of what must necessarily be brief when presented in the form of a Report. It was purposely written to check what Buller considered wilful misrepresentations. Buller himself had no doubt as to the clearness of the Report, for he writes, "The inherent vagueness of the term can throw no doubt on Lord Durham's meaning, because he does not use the term Responsible Government until he has fully explained his meaning without it. $\mathrm{He}$ reports his observations, draws his inferences, and suggests the alterations which he advises in the present system of admin-

1 Ibid., p. 244.

2 Morison, British Supremacy and Canadian Self-Government, p. 243.

I Ibid., p. 241.

${ }^{4}$ British Colonial Policy. 
istering the country. It is only after thus explaining himself, that he remarks that the conclusion at which he arrives, is the same as that which the Reformers of Upper Canada had in view in their demand for responsible government."

In view of the conflict of opinion that has existed as to the precise meaning of Durham's recommendations, it is necessary to quote the exact words of the Report. Durham meant to introduce responsible government into Canada as far as domestic affairs were concerned in the same way as it existed in Great Britain. He said:

It needs no change in the principles of government, no invention of a new constitutional theory, to supply the remedy which would, in my opinion, completely remove the existing political disorders. It needs but to follow out consistently the principles of the British constitution, and to introduce in the government of these great colonies those wise provisions by which alone the working of the representative system can in any country be rendered harmonious and efficient. We are not now to consider the policy of establishing representative government in the North American colonies. That has been irrevocably done; and the experiment of depriving the people of their present constitutional power, is not to be thought of. To conduct their government harmoniously, in accordance with its established principles, is now the business of its rulers; and I know not how it is possible to secure that harmony in any other way than by administering the Government on those principles which have been found perfectly efficacious in Great Britain. I would not impair a single prerogative of the Crown; on the contrary I believe that the interests of the people of these colonies require the protection of prerogatives which have not been hitherto exercised. But, the Crown, must, on the other hand submit to the necessary consequences of representative institutions; and if it is to carry on the Government in unison with a representative body, it must consent to carry it on by means of those in whom that representative body has confidence.

Durham then suggested the means by which such an end could be accomplished:

Every purpose of popular control might be combined with every advantage of vesting the immediate choice of advisers in the Crown, were the Colonial Governor to be instructed to secure the cooperation of the Assembly in his policy by entrusting its administration to such men as could command a majority; and if he were given to understand that he need count on no aid from home in 
any difference with the Assembly, that should not directly involve the relations between mother country and colony. This change might be effected by a single despatch containing such instructions; or if any legal enactment were requisite, it would only be one that would render it necessary that the official acts of the Governor should be counter-signed by some public functionary. This would induce responsibility for every act of the government, and, as a natural consequence, it would necessitate the substitution of a system of administration by means of competent heads of departments, for the present rude machinery of an executive council. The Governor, if he wished to retain advisers not possessing the confidence of the existing Assembly, might rely on the effect of an appeal to the people, and, if unsuccessful he might be coerced by a refusal of supplies or his advisers might be terrified by the prospect of impeachment.

The above passage is remarkably interesting. Certain points in it are quite clear. Above all Durham intended that Downing Street control must cease over the domestic affairs of colonies possessing representative institutions. Similarly the former system by which the executive remained independent of the legislature was to be a thing of the past. That would inevitably happen as soon as the executive was solely dependent for supplies on the legislature. What is most interesting is that nothing is said about a colonial prime minister or a colonial cabinet. The phrase used is "competent heads of departments". The references to the position of the governor allow him to take an active part in colonial politics. He might act as his own prime minister, provided that he could get an Assembly to support him. Such an event occurred under the governorship of Sydenham. Such was the view held by Metcalfe.

On the other hand, the constant comparison drawn by Durham with British parliamentary practice and his own statement, "Nor can I conceive that it would be found impossible or difficult to conduct a colonial government with precisely that limitation of the respective powers which has been so long and so easily maintained in Great Britain," together with his son-in-law Elgin's opinion, "that the real and effectual vindication of Lord Durham's memory and proceedings will be the success of a Governor-General of Canada who works out his views of government fairly," lend support to the view that Durham advocated responsible government as it is now understood.

Durham died in 1840 , and we cannot say for certain what 
his views would have been on the policy of Sydenham and Metcalfe. We can only consider the attitude of his two associates, Buller and Wakefield. A series of articles written by Buller appeared in the Colonial Gazette during the months of December, January, and February, 1839-40, and were published under the title of Responsible Government in the Colonies, on April 16, 1840. His conception of responsible government strongly supports the view that Sydenham and Metcalfe truly interpreted the spirit of the report. Like Durham, he is emphatic on the evils of imperial interference in the domestic concerns of the colonies. The Mother Country "should let the Governor and Assembly get on as best they may, passing such laws and administering affairs by such parties as they may agree on between themselves". Buller never mentions the subject of cabinet responsibility, and he refused to define the contingency on which the governor should dismiss a minister (he does not say ministry) in compliance with the wishes of the representative body. What he does insist on is that the authority of the Mother Country should not be interposed in order to retain in office people who can get no Assembly to work with them. He defined the position of the governor in his relations with the Colonial Office and the Assembly in words that are well worth quoting:

The course of a governor may undoubtedly be generally directed from home to the extent of advising the proposal of particular measures, the rejection of others, or the employment of particular individuals. The Governor instead of acting on his own opinion as the sovereign does, may have his course suggested to him by the Secretary of State; but then he must act on those suggestions as the sovereign here acts on those of her own conscience-that is, within the limits of constitutional possibility... Without saying therefore, that the Colonial Office should give no instructions to Governors, though certainly the less it takes upon itself to instruct those who generally know more about the subject the better-yet, we do say that its instructions should never be positive, but always conditional. The Secretary of State may advise as to men and measures, but he should always limit his advice as to what can be done. He should say, "Pursue such a course, if you can, do not do such a thing if you can help it, employ such persons, exclude others, as far as the Assembly will let you, in short manage to get along with the Assembly as you best may; get it to adopt your policy or do you adopt its policy. If you do not get it to go as I wish, from any fault of your own, and I have reason to think that 
another governor would succeed better, I may have to recall you; but if you get into collision with the Assembly, and cannot get one better disposed towards you, then I certainly must and shall recall you."

It should be added that both Buller and Wakefield supported Metcalfe's policy in 1844. The apparent inconsistency of Durham and his associates in recommending for the colonies responsible government as it existed in Great Britain, and defining it in such a way that the governor could act as his own prime minister, becomes clear when we consider the position of the Crown at home in $\mathbf{1 8 4 0 .}$

It had hardly yet become a convention of the constitution that the monarch must be neutral in domestic politics. Responsible government in England was not fully established until 1832. From 1770 to 1830 there is no instance where a ministry resigned because of a defeat in the House of Commons. The influence and interference of the monarch in domestic politics had been very great. George III aimed at being his own prime minister, and from 1770-1782 he virtually acted as such. In December, 1784, he dismissed the Fox-North ministry, when the India Bill was rejected in the House of Lords; in 1801 he refused to consent to Roman Catholic relief, and Pitt was forced to resign. Pitt afterwards promised, and so did Fox when he took office in 1806, not to revive the subject, and in 1804 George III refused to have Fox in office when requested to do so by Pitt. Responsible government in England made a great advance when the king in 1832 was willing to create new peers in order that the Reform Bill might be passed through the House of Lords. Yet William IV found it difficult to preserve a strict neutrality, and in 1834 dismissed the Whig cabinet of Melbourne. In this case it is true that Melbourne was not unwilling to leave office, but his letter to William IV requested the king either to reconstruct or to take another course. William IV did not, in accordance with modern constitutional practice in England, tell him that he had the royal confidence so long as he kept a majority in the House of Commons, that if he felt unable to remain at the head of the administration it was his duty to resign, nor did he tell him that he might have a dissolution. Instead, the king sent for the Duke of Wellington to form a cabinet. The very fact that such an action was possible, showed how strong the power of the Crown was in practice.

Buller was aware of these precedents, and with this in his 
mind wrote, "The Governor would, in fact, stand in the position of the Crown at home, and it is difficult to make out why the prerogative, which suffices to maintain the balance of power at home, should not be equally competent, to uphold it in a colony." He then alluded to the precedent of 1784 , and was at some pains to show that the authority of the Crown in domestic politics still existed.

Viewed in this light, the struggle that existed in Canada with regard to the position of the governor was perfectly natural. The colonial governor stood in the position of the Crown in England during the reign of William Iv. It was not to be expected that the representative of the Crown in the colonies would exercise less practical influence than the monarch did at home. The attitude adopted by Sydenham and Metcalfe was the logical development of what was meant by Durham to be responsible government. Experience soon proved that it was unworkable in practice. The governor was appointed by the Colonial Office, and was bound by its instructions. So long as he interfered with the domestic affairs of the colony, Downing Street control would exist-the very evil that was intended to be stopped. In the second place, the governor was an experienced statesman, and was fully the equal in talent of the Canadian statesman of the time. He was thus more competent to conduct political warfare than the monarch in England. At the same time, he could not claim the same respect and reverence as the monarch. Canadian politics were then conducted with a bitterness and intensity almost unknown to the English political parties of the time. The conflict naturally arose in an acute form, and criticism of the governor was easier than criticism of the monarch. Thus it was that the transition from a governor who rules to one who reigns but does not rule was settled in Canada during the space of one decade, while in England a similar transition occupied nearly two centuries, without any violent crisis, and was not fully completed until the end of the nineteenth century.

The publication of the last two volumes of the life of Disraeli by Monypenny and Buckle reinforces the view that down to 1880 the Crown still continued to exercise a strong influence over the politics of Great Britain. It is clear that Queen Victoria was a strong partisan of Disraeli's foreign policy, and was filled with a good Tory's dislike of Mr. Gladstone. Not only was this the case, but the Queen went out of her way to show her approval of her favourite prime minister's policy. During the critical 
months of the winter of 1877-1878, when Disraeli's policy was being bitterly attacked by the Liberal opposition, and when there was a lack of unanimity in his own cabinet, the Queen paid a visit to Disraeli at his country house Hughenden. Early in the next year, on January 20, she offered Disraeli the Order of the Garter. In a letter of that date she wrote, "The Queen would wish to confer the vacant Garter on Lord Beaconsfield as a mark of her confidence and support. She and the country have the greatest confidence in him." Disraeli had the good sense, however, to decline an honour offered at such a time.

The Queen did not confine herself to general approval of Disraeli's policy, but her correspondence shows that she found much to criticize in the conduct of the foreign secretary, Lord Derby. Whether her criticism was right or wrong, does not matter. The interesting fact is that she made it without the slightest reserve. A letter of June 25, 1877, well illustrates this fact. Writing to Disraeli, the Queen said: "The reports in Mr. Layard's last letter of the 15th inst., which the Queen saw yesterday, are very alarming. Surely Lord Derby cannot be indifferent to the dangers expressed therein? Warning after warning arrives and he seems to take it all without saying a word? Such a foreign minister the Queen really never remembers."

"The news to-day continues very unpleasant and makes the Queen very anxious. The feeling against Russia is getting stronger and stronger. Only do not delay."

"The Queen has been thinking very much of what Lord Beaconsfield told her, and she thinks that in part public affairs would be benefited if Lord Lyons replaced Lord Derby, as the former has such knowledge of foreign countries. Lord Clarendon had the same and Lord Granville also to a great extent; so had Lord Malmesbury. But unfortunately Lord Derby has not. If he and Lord Salisbury want to resign, however, the Queen thinks they should be told that she could not accept their resignations now, but that they should be relieved later. Could not that be done?"

Two days later the Queen wrote an even more forcible letter to Disraeli. "This delay," she declared, "this uncertainty, by which, abroad, we are losing our prestige and our position, while Russia is advancing and will be before Constantinople in no time! Then the Government will be fearfully blamed, and the Queen so humiliated that she thinks she should abdicate at once."

Queen Victoria did not conceal her grief at the disastrous 
election of 1880 . It was with considerable regret that she discovered that it was impossible to form a Liberal administration without Gladstone as prime minister. Not only did she consult Disraeli during the negotiations with regard to the change of ministry, a course of action that she was not accustomed to follow when Gladstone was prime minister, but she took the dangerous course of asking Disraeli to act as her unofficial adviser. Writing to Disraeli from Baden Baden on April 9, 1880, the Queen declared that, "My great hope and belief is, that this shamefully heterogeneous union-out of mere folly-will separate into many parts very soon, and that the Conservatives will come in stronger than ever in a short time. Possibly a coalition first. But you must promise me for the country's, as well as for my own sake, to be very watchful and very severe, and to allow no lowering of Great Britain's proud position. It must not be lowered. The Army and Navy not diminished, and I look to you for that. Give me that firm promise. I do not care for the trouble of changes of Government if it is to have a secure and safe one, which the new one cannot be. I am shocked and ashamed at what has happened. It is really disgraceful."

The last occasion on which the Queen influenced noticeably the political affairs of the country was in 1894, when Gladstone resigned. The Queen never consulted him as to who should be his successor. Gladstone declared that if he had been consulted, he would have advised the Queen to send for Earl Spencer. The other two obvious choices were Sir William Harcourt, the leader of the House of Commons, and perhaps Lord Kimberley, the leader of the House of Lords. The Queen sent instead for Lord Rosebery, whom she personally knew and liked. It need not perhaps be added that Rosebery was in sympathy with the Queen's imperialism, and that his Liberalism was not sufficiently strong to support the Veto Bill of 1910.

Sufficient has now been said to show that the position of the monarchy was not one of strict neutrality in political warfare during the nineteenth century. This explains the difficulty of a governor in Canada between 1839 and 1849. It was neither the bureaucracy of the Colonial Office, nor the stupidity of the Tory party, that was responsible for the struggle of those years. Lord Durham advocated responsible government, but it was the responsible government of Great Britain of 1840 and not of 1910. Experience proved that this conception had to be widened and enlarged.

K. L. P. Martin 